\title{
Gambaran Partisipasi Masyarakat terhadap Pengendalian Vektor Melalui Kajian Tempat Perkembangbiakan Aedes aegypti di Kota Bandung
}

\author{
Lia Faridah,, ${ }^{1}$ Titik Respati, ${ }^{2}$ Sunarjati Sudigdoadi, ${ }^{1}$ Hadyana Sukandar ${ }^{3}$ \\ ${ }^{1}$ Departemen Mikrobiologi dan Parasitologi Fakultas Kedokteran Universitas Padjadjaran, ${ }^{2}$ Departemen Ilmu \\ Kesehatan Masyarakat Fakultas Kedokteran Universitas Islam Bandung Bandung, ${ }^{3}$ Departemen Epidemiologi \\ Fakultas Kedokteran Universitas Padjadjaran
}

\begin{abstract}
Abstrak
Pada tahun 2014, Bandung memiliki angka kasus demam dengue (DD) tertinggi dari 27 kabupaten/kota di Jawa Barat. Upaya pengendalian DD telah dilaksanakan sejak beberapa dekade yang lalu. Salah satu upaya adalah dengan mengeliminasi tempat perkembangbiakan nyamuk melalui peran serta masyarakat. Penelitian ini bertujuan menilai partisipasi masyarakat Kota Bandung dengan mengetahui tempat-tempat perkembangbiakan Aedes aegypti baik di dalam maupun di luar rumah. Sampling dilakukan di 16 kelurahan di Kota Bandung yang telah dipilih berdasar atas angka kejadian DD, kepadatan penduduk, ketinggian permukaan, dan status sosial-ekonomi periode 2015. Populasi penelitian adalah rumah-rumah yang terdapat di 16 kelurahan tersebut. Jumlah sampel penelitian ini adalah 1.983 rumah yang merupakan perwakilan dari tiap kelurahan. Sampling jentik dilakukan pada berbagai tempat penampungan air, baik penampungan alami maupun buatan di sekitar pemukiman penduduk. Jentik yang ditemukan dimasukkan ke dalam wadah dan dibawa ke laboratorium untuk diidentifikasi dan dihitung jumlahnya. Hasil menunjukkan tempat perkembangbiakan nyamuk yang paling dominan adalah bak mandi (50\%), talang air (24\%), dan dispenser (15\%). Data entomologi diperoleh hasil House index (HI) 24\%, Container index (CI) 12\%, dan Breteau index (BI) 36\%. Hasil tersebut menunjukkan masih kurangnya peran serta masyarakat untuk mencegah DD dengan membasmi tempat perkembangbiakannya dan Kota Bandung masih berpotensi untuk terjadi penyebaran penyakit DD. [MKB. 2017;49(1):43-7]
\end{abstract}

Kata kunci: Aedes aegypti, Bandung, demam dengue, tempat perkembangbiakan, partisipasi masyarakat

\section{Community Participation on Vector Control Based on Aedes aegypti's Breeding Sites in Bandung}

\begin{abstract}
In 2014, Bandung has the highest number of Dengue Fever cases of 27 districts and cities in West Java. Dengue Fever control efforts have been implemented for several decades. One of the efforts is the eradication of the vector breeding site with community participation. The aim of this study was to assess community participation by identifying Aedes aegypti's breeding sites, both indoor and outdoor, in Bandung area. Sampling was conducted on houses in 16 villages throughout Bandung area. The sampling points were selected according to the Dengue Fever event number, population density, height, and socio-economic status. The total sample points were 1983 houses. Larvae from sample points were collected from various water containments, both natural and manmade, around the settlement. The larvae samples were then brought to the laboratory to be identified and counted. Results indicated the dominant breeding sites were bathtub (50\%), gutter (24\%), and dispenser (15\%). Entomological survey resulted in $24 \% \mathrm{HI}, 12 \% \mathrm{CI}$, and $36 \%$ BI. This indicates the lack of community participation in preventing DF by eradicating vector's breeding sites and Bandung is still potential for DF outbreak. [MKB. 2017;49(1):43-7]
\end{abstract}

Key words: Aedes aegypti, Bandung, breeding site, dengue fever, community pasticipation

Korespondensi: Lia Faridah, dr, M.Si, Departemen Mikrobiologi dan Parasitologi Fakultas Kedokteran Universitas Padjadjaran, Jalan Prof. Eijkman No. 38 Bandung, mobile: 08122019367, e-mail: lia.faridah@unpad.ac.id 


\section{Pendahuluan}

Demam dengue (DD) adalah penyakit menular yang disebabkan oleh virus dengue kelompok Arbovirus genus flavivirus. Demam dengue (DD) merupakan penyakit endemis di Indonesia, salah satunya di Kota Bandung. Angka kejadian penyakit dan angka kematian penderita per tahun masih cukup tinggi. Indonesia menduduki urutan tertinggi dalam jumlah kasus di ASEAN. Kepala Dinas Kesehatan Provinsi Jawa Barat memaparkan angka kasus atau penderita DD di Provinsi Jawa Barat dari tahun 2010 hingga tahun 2011 mengalami penurunan. Namun, Kota Bandung memiliki jumlah kasus DD paling tinggi di Provinsi Jawa Barat, terbukti dengan ditemukan 3.132 kasus DD pada tahun 2014 di Kota Bandung yang jauh melampaui jumlah kasus DD di kabupaten/kota lainnya. ${ }^{1}$ Upaya pengendalian DD telah dilakukan sejak beberapa dekade yang lalu. Salah satu upaya yang dilakukan adalah dengan membasmi vektornya, Aedes aegypti. Program utama adalah mengeliminasi tempat berkembang biak nyamuk melalui peran serta masyarakat.

Aedes aegypti umumnya berkembang biak di dalam wadah air buatan yang menampung air bersih. Habitat jentik dapat meningkat secara cepat di wilayah perkotaan. Sampai saat ini belum ada obat atau vaksin yang efektif untuk pencegahan maupun pengobatan. ${ }^{2}$ Penelitian dari berbagai negara menunjukkan pengelolaan lingkungan, terutama wadah penampungan air, sangat penting untuk memastikan hilangnya tempat perindukan nyamuk dan mencegah terjadi kasus DD. ${ }^{3-6}$

Setiap negara memiliki program pencegahan DD yang memanfaatkan partisipasi masyarakat. ${ }^{2}$ Program yang dilaksanakan itu sangat bervariasi mulai dari pemanfaatan media massa di Puerto Rico, pembentukan jejaring collabolator di Vietnam, ${ }^{3}$ mobilisasi masyarakat di Vanuatu, La Untadita; penerapan home-made ovicide di Honduras, sampai pemanfaatan dasa wisma di Purwokerto. ${ }^{7,8}$ Indonesia sendiri telah terkenal dengan program $3 \mathrm{M}$ plus.

Dalam setiap program harus selalu dilakukan evaluasi. Evaluasi sebagai salah satu fungsi manajemen berupaya untuk mempertanyakan efektivitas dan juga efisiensi dari pelaksanaan suatu program sekaligus mengukur hasil-hasil pelaksanaan dengan objektif berdasar atas ukuran-ukuran yang dapat diterima pihak yang mendukung maupun yang tidak mendukung program-program tersebut. Evaluasi partisipasi masyarakat terhadap pemberantasan tempat berkembang biak nyamuk seyogianya dilakukan secara berkala. Oleh karena itu, evaluasi sangat penting agar program pemberantasan sarang nyamuk dengan mengikutsertakan masyarakat berjalan secara optimal.

Khusus di Kota Bandung belum ada data evaluasi maupun penelitian yang terkait tempat berkembang biak Aedes aegypti. Berdasar atas hal tersebut, maka penelitian ini memiliki tujuan mengetahui partisipasi masyarakat melalui identifikasi variasi tempat perkembangbiakan Aedes aegypti di Kota Bandung. Informasi yang diperoleh diharapkan dapat menjadikan dasar bagi pemerintah di dalam menyusun strategi pengendalian Aedes aegypti selanjutnya.

\section{Metode}

Penelitian ini merupakan penelitian deskriptif eksploratif yang dilakukan selama satu tahun, yaitu Januari-Desember 2015. Penentuan daerah survei dilakukan dengan mempertimbangkan 4 parameter, yaitu jumlah kasus DD, ketinggian wilayah dari permukaan laut, tingkat sosial ekonomi, dan kepadatan penduduk. Software ArcGIS dan SPSS ver 17.0 dipergunakan untuk menentukan daerah penelitian dengan stratified random sampling method. Penentuan ketinggian wilayah dilakukan dengan ArcGIS. Berdasar atas analisis maka diperoleh 16 daerah penelitian.

\section{Tabel 1 Lokasi Sampling}

\begin{tabular}{lc}
\hline No & Kelurahan \\
\hline 1 & Cibaduyut Wetan \\
2 & Citarum \\
3 & Tamansari \\
4 & Pasteur \\
5 & Sukabungah \\
6 & Cigadung \\
7 & Sukamaju \\
8 & Cikutra \\
9 & Sukapada \\
10 & Cigondewah Kaler \\
11 & Lebak Siliwangi \\
12 & Antapani Kulon \\
13 & Cijawura \\
14 & Nyengseret \\
15 & Maleber \\
\hline
\end{tabular}


Populasi dalam penelitian adalah rumahrumah yang terdapat di 16 kelurahan tersebut. Jumlah sampel dalam penelitian ini adalah 1.983 rumah yang merupakan perwakilan dari tiap kelurahan. Sampling larva dilakukan di dalam dan di luar setiap rumah dan pada berbagai tempat penampungan air, baik tempat penampungan air alami (TPA) (mis. potongan bambu, tempurung kelapa), TPA buatan (mis. ember, tempayan, dll.) maupun barang bekas/non TPA (mis. ember bekas, ban bekas, dll.). Larva yang ditemukan diambil dengan menggunakan pipet plastik kemudian dimasukkan ke dalam wadah sampel dan selanjutnya dibawa ke laboratorium untuk diidentifikasi dan dihitung jumlahnya.

Data entomologi dilaksanakan dengan cara survei larva nyamuk. Data dihitung dengan mempergunakan indeks larva, yaitu House Index (HI), Container Index (CI), dan Breatau Index (BI). Adapun rumusnya adalah sebagai berikut:

$$
\begin{aligned}
& H I=\frac{\text { Jumlah } \text { rumah positif jentik }}{\text { Jumlah rumah yang diperiksa }} \times 100 \\
& C I=\frac{\text { Jumlah kontainer positif }}{\text { Jumlah kontainer yang diperiksa }} \times 100 \\
& B I=\frac{\text { Jumlah kontainer positif }}{\text { Jumlah rumah yang diperiksa }} \times 100
\end{aligned}
$$

Nilai density figure atau kepadatan populasi nyamuk diperoleh dengan menggabungkan HI, $\mathrm{CI}$, dan BI. Adapun penafsiran hasil density figure adalah sebagai berikut: <1: risiko penularan rendah; $1-5$ risiko penularan sedang; $>5$ risiko penularan tinggi.

\section{Hasil}

Hasil pemeriksaan tempat-tempat perindukan nyamuk terlihat pada Gambar 1 . Jentik nyamuk paling banyak ditemukan di bak mandi rumah penduduk yaitu sebanyak 83 lokasi (50\%), talang air sebanyak 40 lokasi (24\%), dispenser sebanyak 25 lokasi (15\%), drum air sebanyak 16 lokasi (10\%), ember sebanyak 13 lokasi (8\%), tong air sebanyak 8 lokasi (5\%), toilet sebanyak 7 lokasi (4\%), tong jerigen sebanyak 5 lokasi (3\%), akuarium sebanyak 3 lokasi (2\%), wadah di luar sebanyak 2 lokasi, dan sisanya sebanyak masing masing 1 lokasi 1\%).

Hasil identifikasi larva ditemukan 92.01\% Aedes aegypti, 4,17\% Aedes albopictus, dan $3,02 \%$ Culex sp. Hasil survei larva diperoleh perhitungan indeks larva $\mathrm{ABJ}$ sebesar 76\%, HI $24 \%$, CI $12 \%$, dan BI 36\%.

\section{Pembahasan}

Penelitian yang dilakukan di Kota Bandung menunjukkan tempat perkembangbiakan vektor DD lebih dominan ditemukan di dalam rumah daripada di luar rumah. Sebagian besar larva di dalam rumah ditemukan di bak dan dispenser, sedangkan di luar rumah larva paling banyak ditemukan di talang air (Gambar 1). Temuan ini

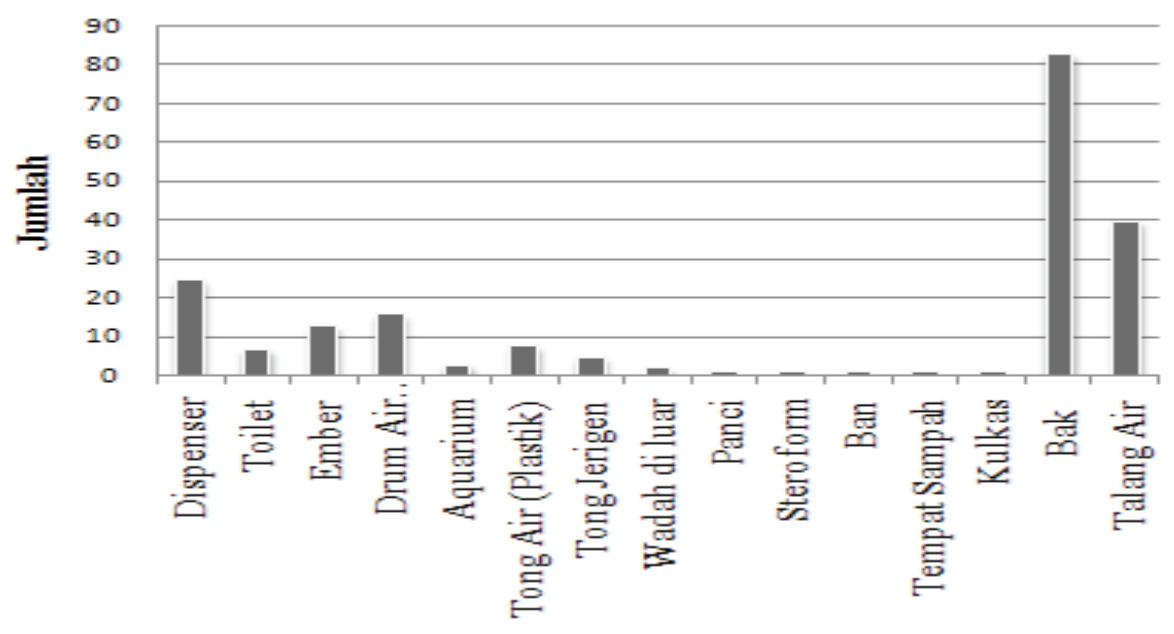

Gambar 1 Tempat-Tempat Perkembangbiakan Nyamuk yang Ditemukan 
Tabel 2 Indeks Larva

\begin{tabular}{lccccccc}
\hline \multirow{2}{*}{ Objek } & \multicolumn{3}{c}{ Jumlah } & \multicolumn{3}{c}{ Indeks Larva (\%) } \\
\cline { 2 - 7 } & Diperiksa & Positif Larva & Negatif Larva & ABJ & HI & CI & BI \\
\hline Rumah & 1.983 & 468 & 1.515 & 76 & 24 & & \\
Kontainer & 5.894 & 704 & 5.190 & & & 12 & 36 \\
\hline
\end{tabular}

sejalan dengan penelitian Widjadja ${ }^{9}$ di Kota Palu bahwa bak mandi merupakan kontainer yang paling banyak ditemukan larva.Hal ini disebabkan oleh kebiasaan masyarakat Kota Bandung yang lebih memilih mandi memakai gayung daripada mempergunakan shower. Selain itu, bak mandi juga digunakan sebagai tempat penampungan air yang digunakan untuk keperluan seharihari sehingga umumnya memiliki volume yang cukup besar dan dapat menyimpan cadangan air dalam waktu yang cukup lama. Lokasi sampling sebagian besar merupakan kawasan urban yang penduduknya sibuk dan kebutuhan air bersihnya cukup tinggi sehingga menyebabkan penduduk jarang sekali membersihkan bak mandi karena khawatir persediaan airnya akan berkurang. Menurut Soegijanto, ${ }^{10}$ tempat berkembang biak Aedes aegypti yang utama di dalam rumah adalah bak mandi, bak wc, tandon air minum, tempaya, gentong tanah liat, gentong plastik, ember, drum dan vas tanaman hias yang kurang diperhatikan kebersihannya.

Berbeda dengan temuan di Kota Bandung, penelitian oleh Nazri dkk. ${ }^{11}$ menunjukkan tempat berkembang biak Aedes aegypti lebih banyak ditemukan di luar rumah dan tempat yang paling dominan adalah tong, drum plastik dan jerigen. Pada kasus Nazri dkk, penduduk mengandalkan air hujan untuk memenuhi kebutuhan air seharihari sehingga ketiga tempat penampungan air buatan tersebut sering digunakan warga untuk memenuhi kebutuhan air mereka. Kasus di Kota Bandung menunjukkan talang air merupakan tempat perkembangbiakan di luar rumah yang paling dominan (Gambar 1). Perbedaan temuan ini menunjukkan bahwa sumber pasokan air menentukan jenis-jenis tempat berkembang biak Aedes aegypti. Perumahan penduduk di Kota Bandung pada umumnya selalu dilengkapi dengan talang air untuk menyalurkan air hujan dari genting ke tanah agar rumah tetap aman dan nyaman. Talang hujan PVC banyak digunakan dengan pertimbangan murah dan mudah didapat. Kelemahan dari penggunaan talang ini adalah daya tahan materialnya. Untuk penggunaan luar dengan kondisi cuaca yang berubah-rubah dapat menyebabkan talang PVC kehilangan kelenturannya, sehingga berakhir dengan retak, kusam, dan berubah bentuk. Akibat berubah bentuk, khususnya untuk talang horizontal maka air tidak dapat mengalir dengan lancar sehingga terbentuklah genangan. Talang air merupakan tempat penampungan air yang digunakan bukan untuk kebutuhan sehari-hari. Lokasi talang air yang sulit dijangkau menyebabkan penduduk sering mengabaikannya sehingga menjadikan

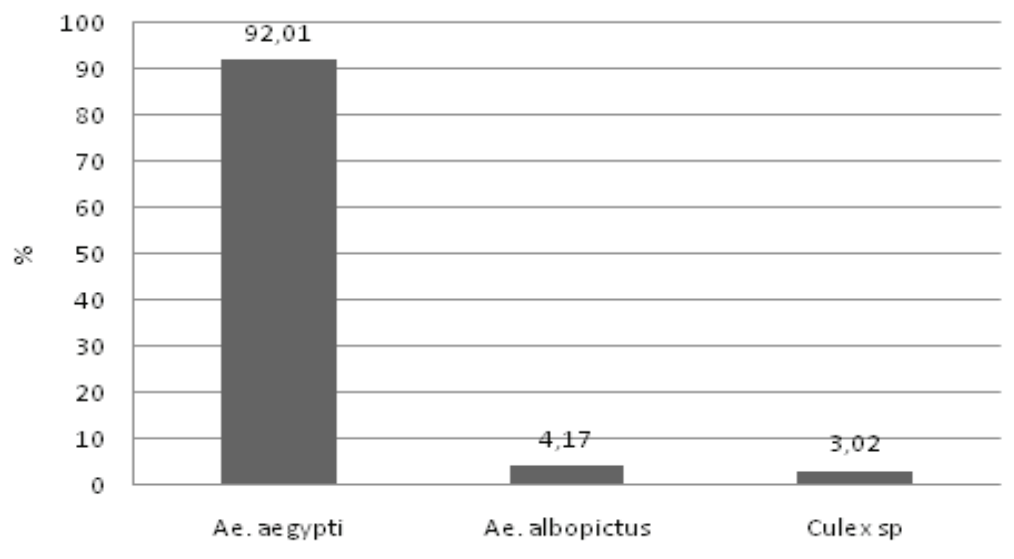

Gambar 2 Proporsi Jentik Nyamuk yang Ditemukan 
tempat berkembang biak nyamuk Aedes aegypti.

Hasil identifikasi larva menunjukan 92,01\% dari total 288 larva yang ditemukan adalah Aedes aegypti (Gambar 2), berbeda dengan hasil penemuan Nazri dkk. yang menunjukkan Aedes albopictus lebih banyak ditemukan, meskipun lokasi sampling sama-sama dilakukan di daerah urban. ${ }^{11}$ Perbedaan ini dapat terjadi oleh karena lokasi sampling di Kota Bandung umumnya merupakan daerah padat penduduk dan minim ruang terbuka hijau.

Hasil survei larva dari 1.983 rumah diperoleh nilai ABJ sebesar 76\%, HI 24\%, CI 12\%, dan BI $36 \%$. Hasil perhitungan HI dan CI diperoleh angka kepadatan jentik dengan density figure $=4$ sedangkan perhitungan BI diperoleh density figure=5, yang berarti bahwa Kota Bandung mempunyai risiko sedang terhadap penularan penyakit DD. Hasil tersebut menunjukkan bahwa peran serta masyarakat untuk mencegah DD dengan membasmi tempat perkembangbiakan vektor masih sangat kurang dan Kota Bandung berpotensi untuk terjadi penyebaran penyakit DD.

\section{Daftar Pustaka}

1. Dinas Kesehatan Provinsi Jawa Barat. Profil Kesehatan Tahun 2014. 2014;21(83):24.

2. Elder J, Lloyd LS. Achieving behaviour change for dengue control: methods, scaling-up, and sustainability. Report of the Scientific Working Group on Dengue, 1-5 October 2006. Geneva: WHO; 2007.

3. Nam VS, Kay B, Yen NT, Ryan P, Bektas A. Community mobilization, behaviour change and biological control in the prevention and control of dengue fever in viet nam. Dengue Bull. 2010;28(2010):57-61.
4. Arunachalam N, Tyagi BK, Samuel M, Krishnamoorthi R, Manavalan R, Tewari SC, dkk. Community-based control of Aedes aegypti by adoption of eco-health methods in Chennai City India. Pathog Glob Health. 2012;106(8):488-96.

5. Danis-Lozano R, Rodríguez MH, HernándezAvila M. Gender-related family head schooling and Aedes aegypti larval breeding risk in Southern Mexico. Salud Pública de México. 2010;44(3):237-42.

6. Suwannapong N, Tipayamongkholgul M, Bhumiratana A, Boonshuyar C, Howteerakul $\mathrm{N}$, Poolthin S. Effect of community participation on household environment to mitigate dengue transmission in Thailand. Tropical Biomed. 2014;31(1):149-58.

7. Sommerfeld J, Kroege A. Innovative community-based vector control interventions for improved dengue and Chagas disease prevention in Latin America: introduction to the special issue. Trans R Soc Trop Med Hyg. 2015;109(2):85-8.

8. Arunachalam N, Tana S, Espino F, Kittayapong P, Abeyewickreme W, Wai KT, dkk. Ecobio-social determinants of dengue vector breeding: a multifactorial study in urban and periurban Asia. Bull WHO. 2010;88(3):17384.

9. Widjaja J. Keberadaan kontainer sebagai faktor risiko penularan demam berdarah dengue di Kota Palu Sulawesi Tengah. J Aspirator. 2011;3(2):82-88.

10. Soegijanto S. Demam berdarah dengue. Surabaya: Airlangga University Press; 2006.

11. Nazri CM, Abu HA, Rodziah I. Habitat characterization of Aedes sp. breeding in urban hotspot area. Procedia-Social Behav Sci. 2013;85(2013):100-9. 